\title{
Saudades de Timor: memórias de mais um viajante?
}

\author{
Alan Silvio Ribeiro Carneiro ${ }^{1}$
}

Timor pertence aos Timorenses, tão portugueses por causa dos padres não necessariamente, mas padres-pais, ou lá o que são ou não.

Paternidade não é devoção. Eu trato os timorenses como amigos ...irmãos que me necessitam.

(in CINATTI, Ruy. Passos Perdidos, 1996, p. 83)

\section{Prólogo}

Ao refletir acerca do que escrever neste diário, pensava em como escapar e não escrever mais um diário sobre os "outros", como não se filiar a uma tradição de visões de viajantes, de olhares de colonizadores que foram ao oriente para encontrar, como nas palavras de Said (2003), o oriente que sempre conheceram, de povos exóticos, com costumes curiosos e linguas incompreensiveis, como não ser o viajante que ao escrever e relatar suas viagens com o tempo, construiu uma imagem do

\footnotetext{
${ }^{1}$ Licenciado em Letras, Mestre em Teoria e História Literária e Doutorando em Linguística Aplicada, na Área de Multiculturalismo, Plurilinguismo e Educação Bilíngue, na UNICAMP (Bolsista do CNPq). Foi bolsista entre 2008 e 2009, do Programa de Qualificação de Docente e Ensino de Língua Portuguesa em Timor-Leste da CAPES, atuando como professor de português na Universidade Nacional de TimorLorosa'e (UNTL).
} 
outro, a partir das suas imagens, apagando lentamente as possibilidades do outro de constituir suas imagens de si.

A história registrada de Timor começa justamente com os relatos de viajantes, primeiramente de chineses que desde muito tempo navegavam pela região, podendo ser conhecida posteriormente a partir de dezenas de relatos de viajantes europeus que passaram pelo seu território desde o início da primeira globalização, iniciada com a era das grandes navegações européias. Localizado entre o Índico e o Pacífico, um pouco mais ao sul da grande rota de navegação que liga a Índia à China, Timor entrou para o mapa da história ocidental como um dos pólos de produção de especiarias, o país era produtor do sândalo branco "salutífero e cheiroso" que aparece na epopéia camoniana. Pigafetta, por exemplo, que participou da primeira viagem de circumnavegação, como pajem do capitão-mor Fernão de Magalhães, foi um dos primeiros ocidentais a relatar o que viu em Timor, tendo em vista o produto que notabilizava estas terras:

Estes povos são gentios. Quando vão cortar o sândalo (eles mesmos utilizam este nome), aparece-lhes o demónio sob diversas formas, dizendo-lhes que lhe podem pedir tudo o que quiserem, com o que se põem enfermos durante alguns dias. (...) Em todas as ilhas deste arquipélago que visitámos reina o mal de Job, e mais nesta ilha que em todas as demais; chamam-lhe for franchi, ou seja, "mal português" (PIGAFETTA, 1995,p. 83).

Pigafetta foi um desses viajantes que alimentou a imaginação européia. Ao descrever o processo de extração do sândalo tão apreciado na Europa, ele precisava deixar claro que havia magia e seres demoníacos a presidir o processo. Pigafetta identifica em alguma espécie de problema de pele local, sobre o qual não se tem informações, o que ele denomina, aparentemente de forma jocosa, como "mal português", associando a doença que encontrara à sífilis que assolava a Europa no século XVI.

Relatos como o de Pigaffetta sobre Timor se multiplicariam ao longo do tempo, passariam por lá outros navegadores, missionários e a 
partir do século XVIII, governadores e representantes do reino português que passaram a se fixar na ilha, ainda que por pouco tempo, para administrar o território. Timor teve mais de trezentos governadores desde 1700. Para os que vieram depois dos primeiros viajantes as imagens que eles desenharam do território foram se sobrepondo e Timor foi aos poucos sendo construído no imaginário português como território miserável e insalubre, cheio de pobreza, um lugar para degredados. Esta construção fez com que ao longo do tempo as imagens construídas de Timor se tornassem a realidade para o olhar do viajante ocidental, uma vez que para ele, importa menos o que de fato vê e mais se o que vê está de acordo com o que imagina que veria.

No espaço destas páginas não poderei retomar as dezenas de narrativas sobre Timor que informam uma história do território pelos “olhos do império", na expressão feliz, de Mary Louise Pratt (1999), mas penso que é interessante pensar que Timor ainda é um território de viajantes no momento atual. Mesmo tendo sido encerrado o período de dominação estrangeira institucionalizada, da colonização portuguesa (até 1975), da ocupação indonésia (até 1999) e da administração da ONU (até 2002) - Timor continua sendo frequentado por estrangeiros com olhares imperiais, agora, eles são trabalhadores internacionais, principalmente dos países desenvolvidos que estão a circular por diversos países em desenvolvimento trabalhando em agências internacionais ou ONGs, ganhando por vezes trinta, quarenta vezes mais que os trabalhadores locais. Muitas vezes estes "cooperantes" apenas prestam consultoria que duram não mais do que quinze ou trinta dias, embolsando somas inimagináveis para o trabalhador comum. Muitos destes, com as possibilidades oferecidas pela internet descrevem, como os velhos viajantes europeus, suas impressões sobre este mundo exótico, por meio de blogs e outros artefatos eletrônicos. Segue um relato que selecionei na internet e que registra uma imagem destes novos viajantes sobre Timor, descrevendo o que há de exótico no território e reatualizando as narrativas imperiais: 
(...) os portugueses não foram dos melhores colonizadores do mundo - diga o que quiser sobre os britânicos, em nosso império, nossa tendência era erigir construções substanciais e educar ao menos alguns nativos, o que fez com que, quando saíssemos, nós deixássemos funcionando uma burocracia e alguma infra-estrutura. Os leste-timorenses foram deixados sem nada e na pobreza. Logo depois da saída dos portugueses, os indonésios decidiram reivindicar TimorLeste como deles. (...) De volta aos australianos. Eles estavam tão envolvidos com o país que eles decidiram tomar conta dos campos de petróleo deles. (...) Mesmo com o tratado tendo sido assinado por uma força ocupante ilegal, Canberra insistiu que Timor honrasse os acordos. Os ETs (Desculpe - eu não pude resistir a essa) estão furiosos, mas não há nada que se possa fazer, quando a sua população total é do tamanho de meia dúzia de subúrbios de Sidnei juntos (...) (FOREMAN, M.) ${ }^{2}$

Provavelmente o autor do texto, ao decidir publicá-lo na internet, não viu nenhum problema no que está afirmando, para ele é como se o que disse fosse um fato e fosse conhecido de qualquer leitor que decidisse procurar estas informações no Google. É como se fosse evidente que "os britânicos foram melhores colonizadores que os portugueses", que "a reivindicação indonésia de Timor é natural”, que é óbvio que "os australianos vão assumir o controle do petróleo de Timor". Mas o pior na mensagem do autor é que não parece ser problemático fazer um trocadilho e chamar os timorenses de "ETs", descaracterizando a própria humanidade deles.

Entre o relato de Pigafetta e o de Foreman se fortalece o olhar branco, europeu, ocidental sobre o mundo subdesenvolvido. Curiosamente Foreman é gay, o que impediria que eu dissesse que este olhar é também heterossexual, mas ao mesmo tempo serve para evitar qualquer idealização que iguale situações de marginalização. Ser um

\footnotetext{
${ }^{2}$ (...) the Portuguese were not one of the world's better colonisers - say what you like about the Brits, in our Empire we tended to erect substantial buildings and educate at least a few natives so that when we pulled out we left functioning bureaucracies and at least some infrastructure. The East Timorese were left with nothing but poverty. Shortly after the Portuguese headed for home, the Indonesians decided to claim ET as theirs. (...) Back to the Australians. They're so involved in the country that they've decided to take over the country's oilfields. (...) Even though the treaty was signed by an illegally occupying force, Canberra insists that East Timor honour the agreement. The ETs (I'm sorry - I couldn't resist that one) are hopping mad, but there's nothing you can do when your total population is about the size of a couple of Sydney's suburbs put together (...) (FOREMAN, M.)
} 
gay europeu certamente é muito diferente de ser um gay angolano ou timorense. Queria antes de predispor-me a narrar a minha viagem a Timor, contrastar estes relatos, para quem sabe ficar deste modo menos refém de suas perspectivas. Fico preocupado por as vozes de Timor ainda não poderem ser ouvidas, por as suas narrativas, mesmo as mais engajadas sobre o que ocorreu no território, ainda serem feitas pelos estrangeiros, pelos visitantes que estão de passagem. Por isso, ao voltar para minha posição de viajante, quero evitar cair nas garras discursivas deste olhar imperial, ciente de que não posso dar voz ao outro, mas que posso ao menos escutá-la.

O deslocamento geográfico espacial pelo qual passei, entre 20082009, ao ir para Timor, impactou simbolicamente a leitura que faço do mundo que sempre conheci. A partir da viagem, muitas das minhas certezas, principalmente as que construí ao longo da minha formação universitária e política foram desestabilizadas. Mas não de imediato, isso levou mais que o tempo da viagem, foi nesse longo tempo de retorno, onde pesa o esquecimento, que a rememoração, involuntária e voluntária passou a vir, às vezes como saudade, como tristeza ou preocupação. Sabendo de antemão ser improvável uma aproximação que não evidencie as fissuras, as diferenças, quero percorrer neste espaço, algumas das minhas memórias de Timor sob o signo da saudade, não da distância geográfica, mas cultural, que sei não poder superar, quero crer, como Mary Louise Pratt (1999, p. 32) numa perspectiva de contato que põe em relevo como os sujeitos são constituídos nas e pelas suas relações com os outros.

\section{Ir para Timor}

Timor-Leste não era para mim mais do que o nome de um país asiático distante quando fui selecionado pela CAPES para participar do Programa de Qualificação de Docente e Ensino de Língua Portuguesa em Timor-Leste, em junho de 2008. Perto de terminar o mestrado em literatura brasileira, na UNICAMP, desanimado com a vida acadêmica, 
fui imbuído mais de um espírito aventureiro do que do espírito de pesquisador. Imaginava, pela conversa da entrevista, que eu seria deslocado para um lugar timorense remoto e distante, em meio às montanhas ou numa praia inacessivel. Pensava que eu iria ensinar português para pessoas que nem conheciam o idioma, num lugarejo qualquer. Separei livros, roupas, calçados que pudessem servir nesta empreitada, preparei-me como se fosse acampar. Antes da viagem vi o filme da atriz e cineasta brasileira Lucélia Santos, Timor, o massacre que o Mundo não viu (2001) e alguns dias antes de partir ganhei do antropólogo Omar Ribeiro Thomaz, o livro organizado por outros dois antropólogos brasileiros, Kelly Silva e Daniel Simião, denominado TimorLeste por trás do palco: Cooperação internacional e dialética da formação do Estado (2007).

O filme de Lucélia Santos deixou-me sensibilizado para a história do povo timorense: os seus vínculos com Portugal e com a língua portuguesa; os 24 anos de ocupação indonésia; os momentos iniciais da reconstrução política, em 1999-2000; o papel da ONU e do brasileiro Sérgio Vieira de Mello no processo de independência. O filme fez com que eu passasse a ver a viagem como uma missão de solidariedade. Dias mais tarde mergulhei no livro dos antropólogos brasileiros durante a longa viagem da cidade de São Paulo à capital timorense Díli, intercalada de paradas em diversos portos de passagem, Santiago, no Chile, Auckland, na Nova Zelândia e por fim Sydney e Darwin, na Austrália. No caminho, enquanto estava lendo o livro, foi se construindo outra imagem de Timor, muito diferente dos momentos prévios à minha partida quando vi o filme e passei a questionar a minha missão internacional de solidariedade.

Eu mantive o espírito aventureiro, mas tinha um olhar extremamente crítico ao que eu estava indo fazer em Timor, a obra havia me ajudado a compreender que a cooperação internacional definitivamente não era um instrumento somente para ajudar na reconstrução de um país, era um instrumento para demonstração de poder político no âmbito internacional. O livro contribuiu para que eu 
percebesse que guerras, desastres naturais, a construção ou reconstrução de países representam grandes negócios para as agências internacionais, para os países desenvolvidos ou países que desejam ter visibilidade politica no plano global como o Brasil. Mas não só isso, já que as elites locais se beneficiam, e muito, desta dinâmica, uma vez que o afluxo de recursos internacionais gera desenvolvimento, mas as suas benesses são apenas para alguns. Um dos artigos do livro escrito por um timorense resumia bem o que esta situação representava:

Enfim podemos dizer que entender a assistência internacional em Timor-Leste é um dilema. Teoricamente, os doadores dizem que ela é uma forma de cooperação para ajudar o país a atingir sua independência. $\mathrm{Na}$ realidade porém os doadores não usam seu dinheiro para fortalecer nossa independência, mas para nos forçar a sermos novamente subservientes (NEVES, 2007,p.117).

\section{Chegar a Timor}

Sem ilusões, cheguei em Díli, em um final de tarde, no aeroporto as placas de propaganda indiciavam a complexa situação linguística local: o anúncio de uma instituição financeira indonésia, o banco Mandiri, estava em indonésio; curiosamente a propaganda do banco australiano Australian and New Zealand (ANZ) estava em português, a língua oficial; o outdoor de uma organização não-governamental (ONG) norte-americana, Buy Local estava em inglês, com a tradução para a língua co-oficial, o tétum. 


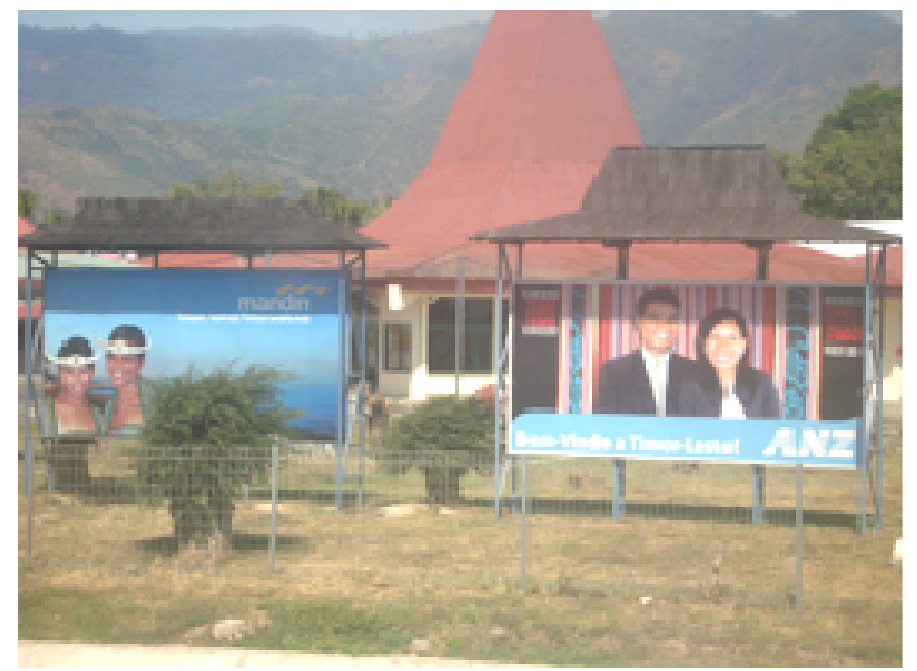

Placas em indonésio e português no Aeroporto, Díli.

Alan Carneiro - Agosto de 2008

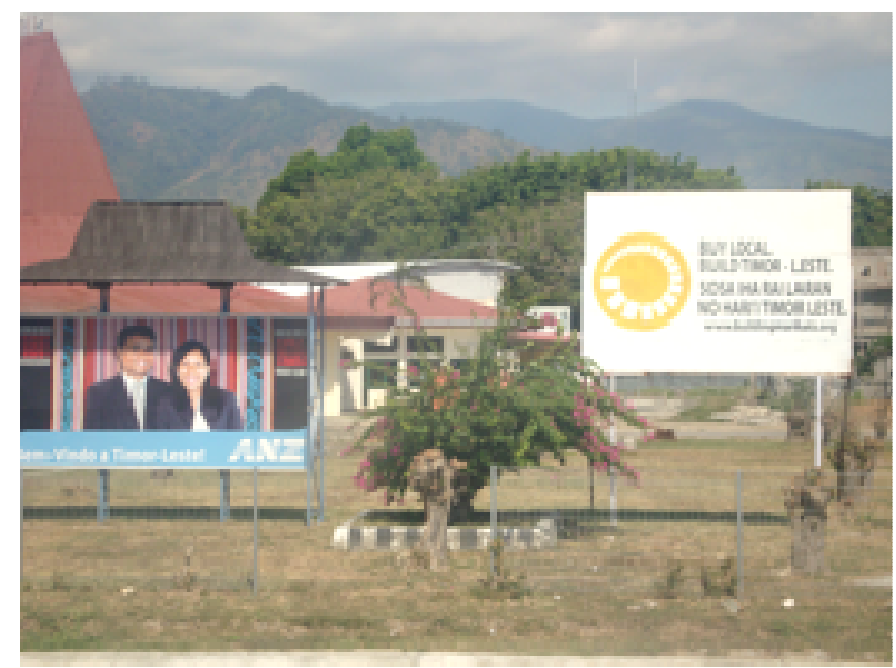

Placa em português, inglês e tétum no Aeroporto, Díli.

Alan Carneiro - Agosto de 2008

Fui recepcionado pelo simpático coordenador da missão brasileira em Timor, o Professor Fernando Spagnolo, e o pró-reitor de assuntos acadêmicos da UNTL, Professor Miguel Maia. Soube logo que não iria viajar para o interior e que ficaria em Díli, trabalhando na Universidade Nacional Timor Lorosa'e (UNTL). Um tanto decepcionado, no caminho, fui observando a cidade: vendedores nas ruas; pequenas aglomerações de barracas de feiras; um ou outro supermercado grande; muitos 
carros, vários deles com a denominação UN (United Nations); casas timorenses sempre ajardinadas, com muitas plantas; em algumas ruas pequenas, porcos e cabras circulando; vi também alguns carrinhos de comida, que mais tarde soube serem herança indonésia.

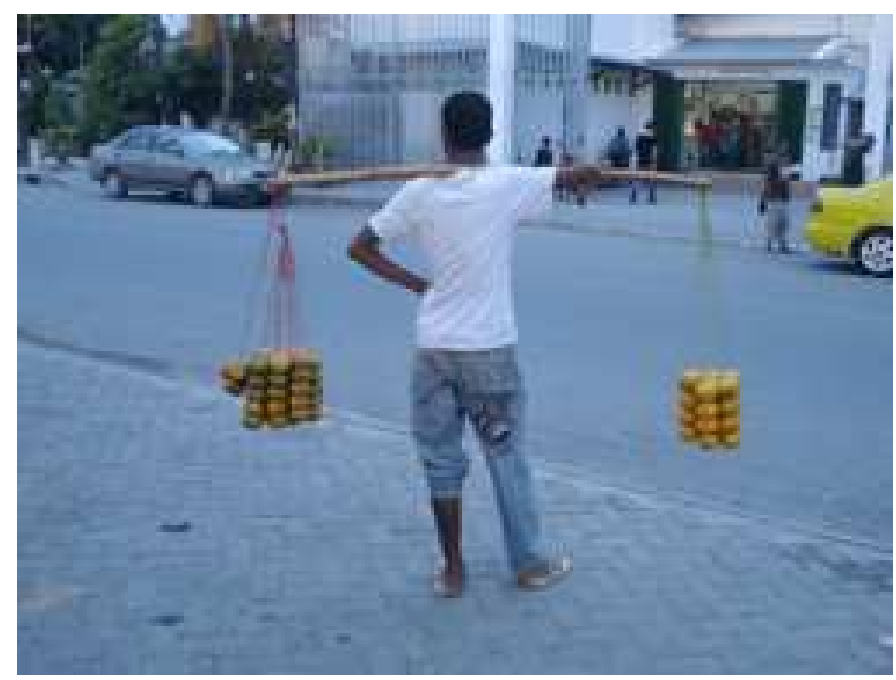

Vendedor de rua, Díli. Alan Carneiro - Outubro de 2008

Ao longo dos dias, ao percorrer a cidade, a diversidade de línguas utilizadas não só nas placas e sinalizações, mas também nos diversos contextos de interação surpreendeu-me ainda mais: pessoas falando em tétum nas ruas, nas feiras e nas casas; professores portugueses e brasileiros ensinando e interagindo em língua portuguesa nas universidades e em cursos de formação de professores; trabalhadores internacionais dos mais diversos países conversando em inglês nos restaurantes, nas agências internacionais e nas sedes de ONGs; comerciantes de diferentes nacionalidades, mas principalmente indonésios e chineses, utilizando o indonésio e o inglês, sendo que dentre estes últimos ainda se via alguns que utilizavam o hakka ou o yue, linguas vindas do sul da China que estão presentes no país desde tempos remotos.

Nos primeiros dias fiquei hospedado em um hotel, mais tarde, fui morar em uma pequena hospedaria de um chinês no bairro do Colmera, o centro comercial local. Soube que os chineses sempre foram os donos de estabelecimentos comerciais em Timor, mais tarde, descobri que isso ocorria mesmo nos lugares mais remotos. Mudei ainda mais algumas 
vezes até achar um lugar tranquilo, onde pudesse sentir que estava em casa. A comida no início sabia diferente, mas muito saborosa, e por isso talvez eu ainda tenha guardado na boca o sabor da primeira catupa ${ }^{3}$, com o gosto do arroz cozido no óleo de coco. Mas nestes primeiros tempos eu rodava mais pelos restaurantes frequentados pelos internacionais, com comida de diferentes países, cada uma com um gosto e um sabor diferente. Mais tarde comecei a cozinhar em casa, aproveitando o fato das feiras de Timor serem ricas em vegetais e dos produtos locais serem todos orgânicos.

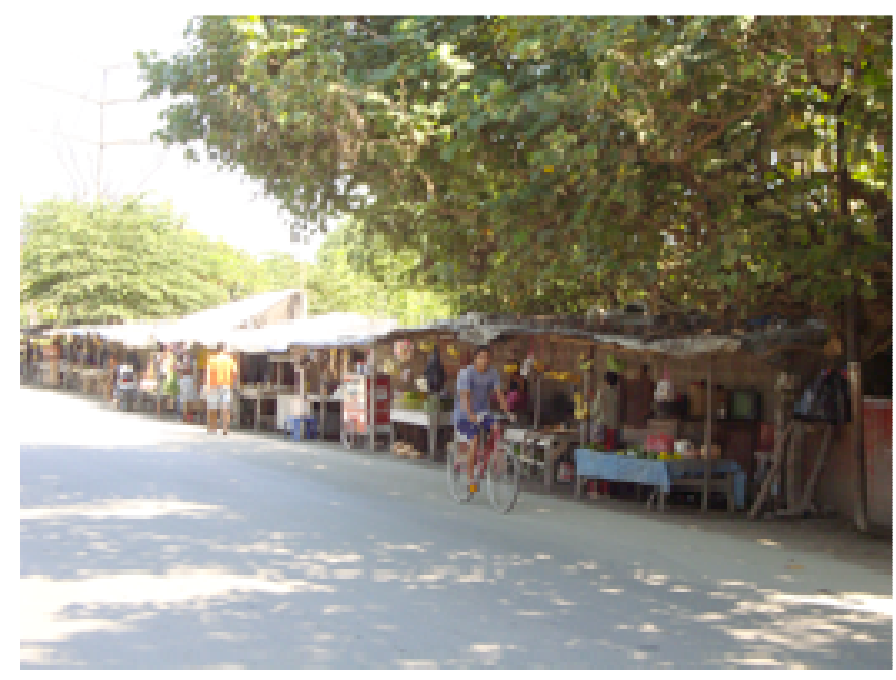

Feira no Bairro de Becora, Díli. Alan Carneiro - Abril de 2009

Comprei uma bicicleta, que seria minha companheira ao longo de um ano de estada em Timor e adquiri rapidamente o hábito de ir dia sim, dia não à Praia da Areia Branca e do Cristo-Rei no fim de tarde, mais para ver o mar, do que para ficar entre os malaes ${ }^{4}$ que dominavam a área. Ao longo do tempo fui conhecendo todas as feiras de Díli que eram a minha ponte cotidiana de contato com os timorenses. Lamentavelmente a maior parte delas desapareceu com as operações de reurbanização que jogou estes trabalhadores para bairros distantes.

\footnotetext{
${ }^{3}$ Trata-se de arroz cozido embrulhado em folha de bananeira no formato de pequenos retângulos.

${ }^{4}$ Estrangeiro em tétum e em outras línguas timorenses.
} 


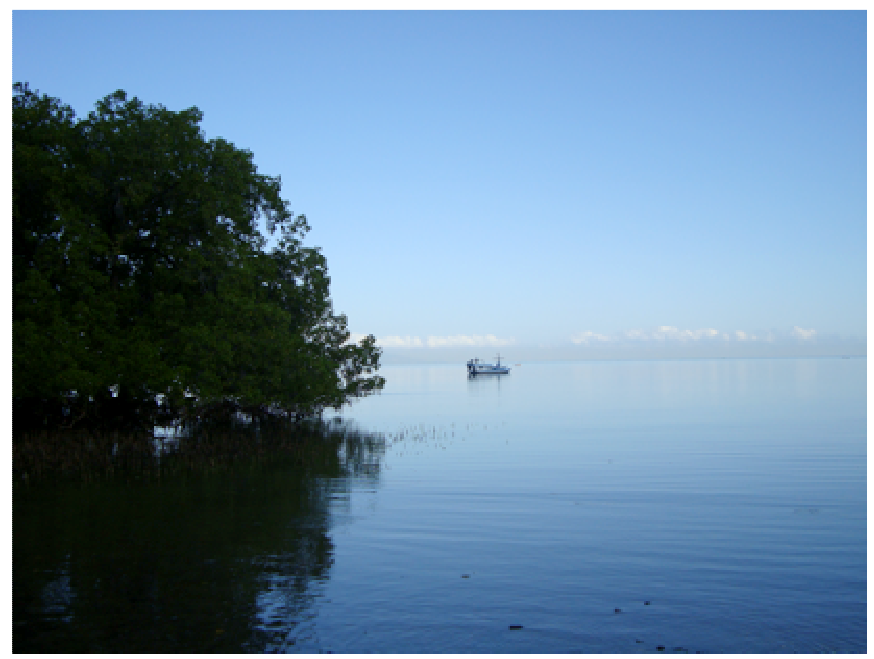

Caminho para Praia da Areia Branca, Díli.

Alan Carneiro - Abril de 2009

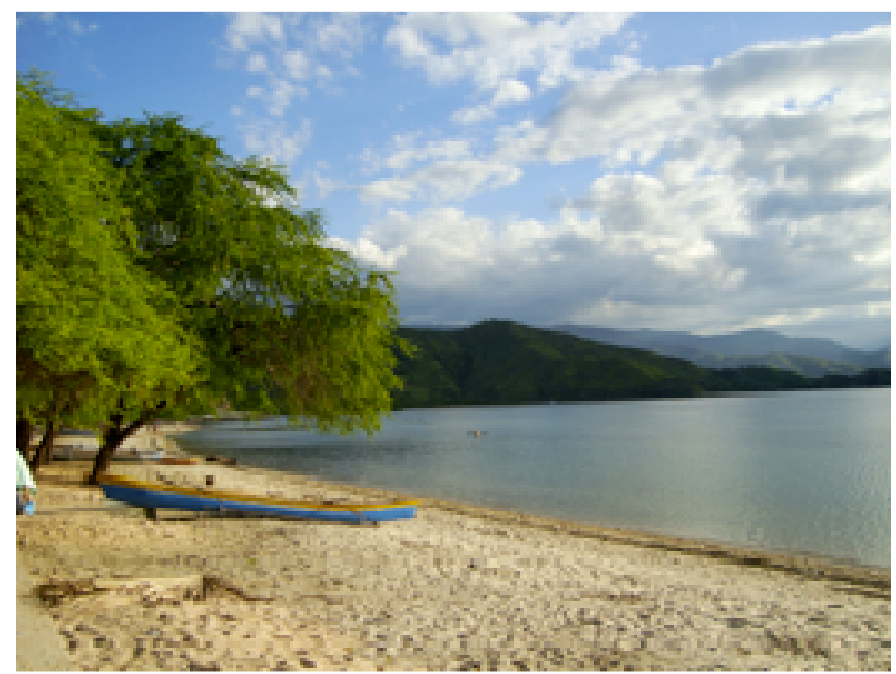

Praia da Areia Branca, Díli. Alan Carneiro - Abril de 2009

\section{Ser professor de português em Timor}

Cheguei na universidade sem saber muito bem o que iria fazer. A nossa sala era no charmoso prédio da Faculdade de Educação, onde antes funcionava o Liceu Dr. Francisco Machado. Na chegada descobri que eu seria professor de um curso de especialização lato sensu em educação na área de língua portuguesa. Fiquei assustado pois não considerava que as minhas experiências fossem suficientes para tal. Além do mais, não sentia que estivesse preparado, não trouxera livros 
acadêmicos e não sabia qual seria o perfil dos estudantes. Na verdade não tinha nem roupas para ser um professor universitário e não demorou muito para que eu percebesse as faces coradas com um sorriso no canto da boca ao verem que eu estava sempre com a mesma velha bermuda e a camisa sem passar. Com o tempo fiquei mais formal, mas não tinha como esconder a minha brasilidade, denunciada em cada palavra e em cada gesto.

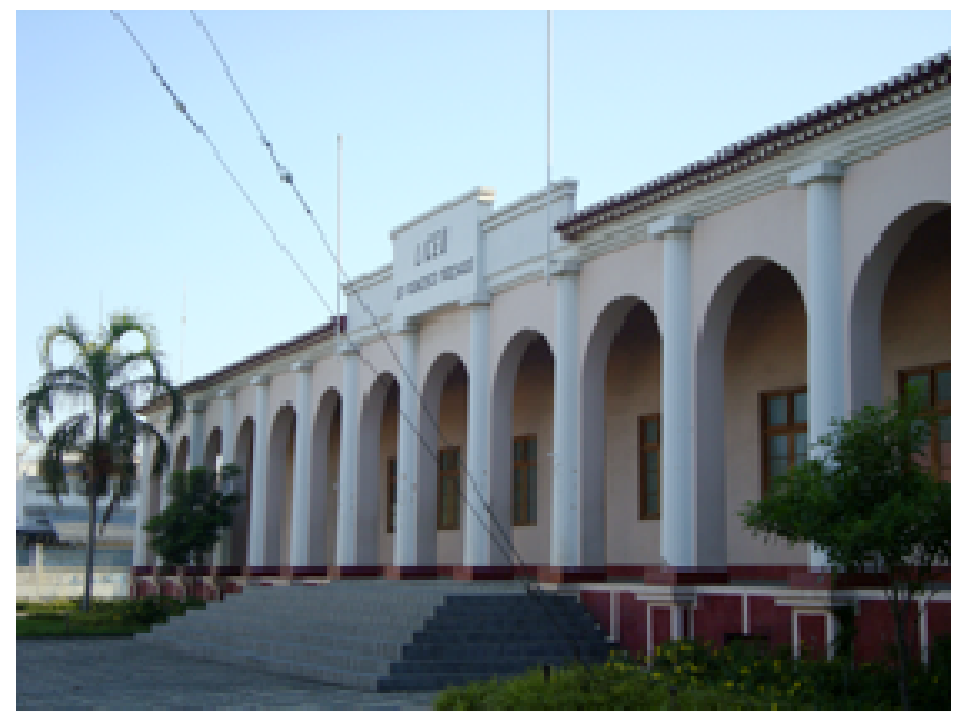

Edifício do Liceu Dr. Francisco Machado, Díli.

Alan Carneiro -Abril de 2009

O curso estava em sua segunda edição e era o primeiro curso de pós-graduação de Timor-Leste, o que dava um peso ainda maior para a minha tarefa e de meus colegas. O grupo da pós era composto por oito professores mais a coordenadora. Nós tínhamos como função começar a desenvolver a cultura de pesquisa ainda incipiente na universidade e abrir o caminho para futuros cursos de mestrado e doutorado. O nosso curso era composto por quatro áreas diferentes, Educação Ambiental, Educação e Ensino, Ensino de Língua Portuguesa e Gestão da Educação. Os responsáveis pela área de lingua portuguesa eram apenas eu e mais uma colega, por coincidência também da UNICAMP, Simone Silvestre.

Nós dois organizaríamos todas as etapas do curso na nossa área: o planejamento pedagógico, o processo seletivo, as disciplinas do núcleo 
específico e a orientação de monografias. Infelizmente ou felizmente no processo seletivo para a área de lingua portuguesa foram aprovados somente sete alunos para um total de quinze vagas, por um acaso, como é comum na nossa área, todas mulheres.

Metade da turma havia sido formada no curso de Licenciatura em Lingua Portuguesa e Culturas Lusófonas, fruto de uma parceria entre o Instituto Camões e a Universidade Nacional Timor Lorosa'e. Uma era formada em língua inglesa, outra em língua malaio e outra no Curso de Formação de Professores denominado Bacharelato. A maioria delas entre os seus quarenta e cinquenta anos. Tempo suficiente para terem vivenciado o final da colonização portuguesa, a ocupação indonésia e o processo de construção de Timor-Leste como um país independente.

Não tem um dia que estando com elas, eu não tenha aprendido mais do que ensinei. A nossa convivência cotidiana era permeada de risos, principalmente delas que achavam engraçado o professor brasileiro cheio de conceitos, língua materna, educação bilíngue, multilinguismo, entre outros tantos que por vezes soavam opacos em um país com mais quinze linguas e outros tantos dialetos, para elas que sabiam falar bem ao menos três ou quatro linguas diferentes, estas distinções não eram tão relevantes.

Com elas cotidianamente fui aprendendo também algo sobre a cultura timorense, tanto porque me ensinavam nas nossas conversas como também porque seus projetos de monografia queriam investigar temas locais. Ao longo do meu primeiro semestre em Timor, devorei tudo que pude achar nas parcas bibliotecas timorenses sobre o pequeno país. No Brasil, é comum um professor dizer, "este tema eu não tenho condições de orientar", eu não sentia que eu tivesse esta opção e assumi com elas, corajosamente, a perspectiva de investigar através da lingua portuguesa, as línguas e as culturas de Timor. Conforme o tempo passava, percebi no dia a dia, a função que estas professoras exerciam. Eram guardiãs não somente da língua portuguesa, que aprendi com elas ser uma língua timorense e um patrimônio de Timor, mas também das diversas outras linguas e culturas do território. 
A doce voz das minhas alunas, transitando entre línguas, culturas, visões de mundo e política, eram para mim as vozes que desfaziam o silêncio de quem não ganhara projeção no processo de reconstrução do novo país, do que não era contado na história oficial nem nas línguas oficiais. Nas suas pesquisas elas amplificavam as vozes dos velhos lia-nain, os donos da palavra nas culturas tradicionais de Timor e as vozes das crianças e jovens, seus alunos e alunas, nos seus esforços para aprender português.

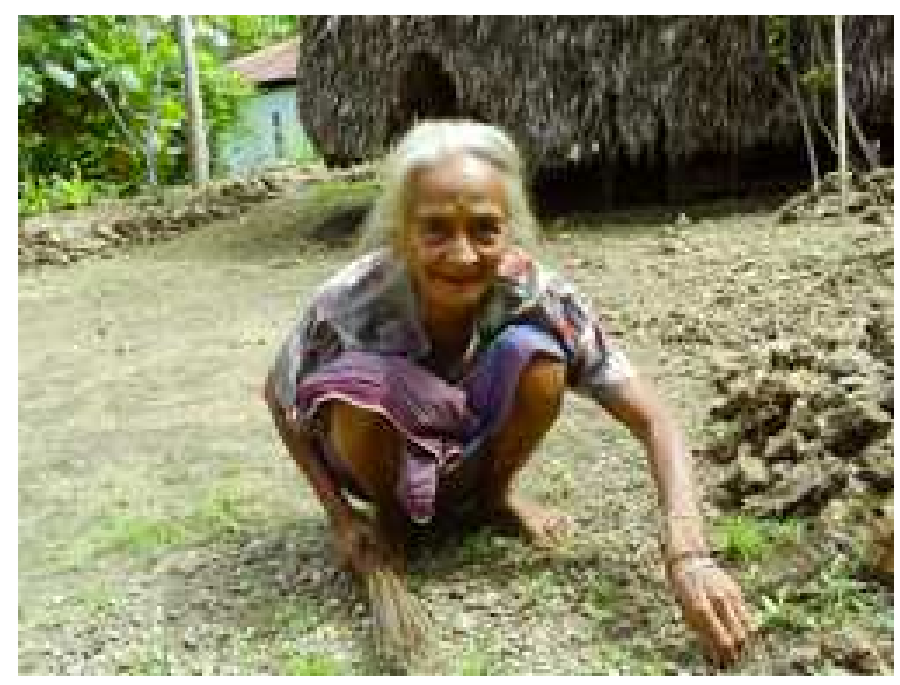

Mulher recolhendo plantas para ritual, Balibó.

Maria Filomena Soares - Janeiro de 2009

(Pesquisa para Monografia de Conclusão de Curso)

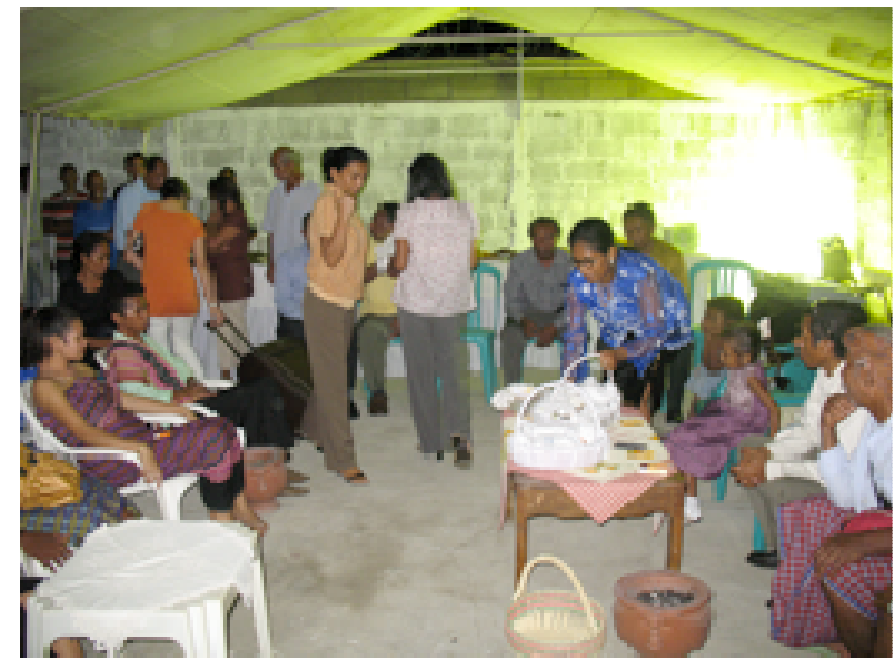

Festa de ritual de casamento (Barlaque), Díli.

Maria da Cunha - Fevereiro de 2009

(Pesquisa para Monografia de Conclusão de Curso) 


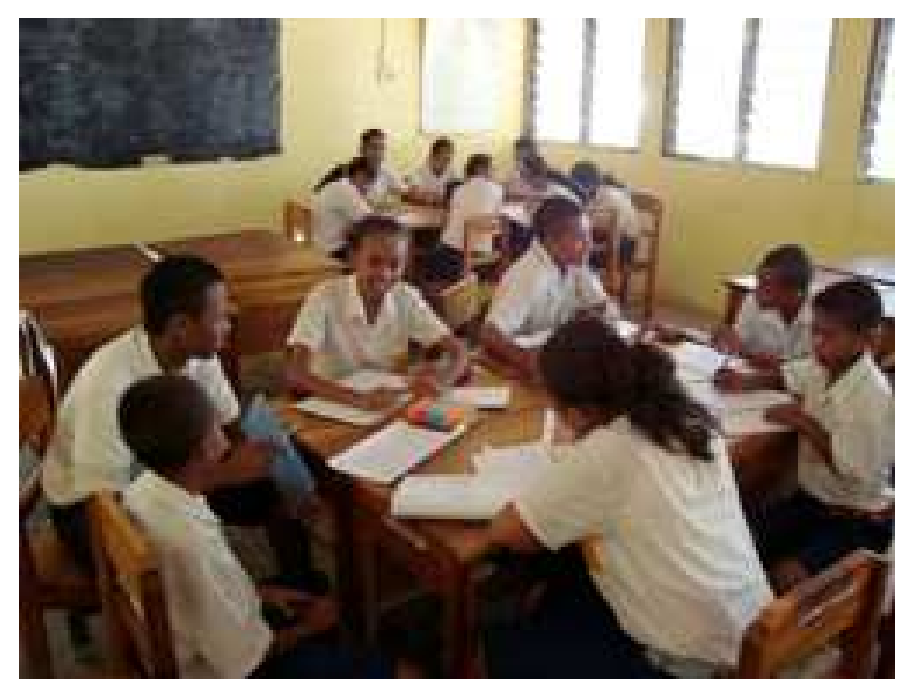

Sala de Aula Escola Sagrado Coração de Jesus em Becora, Díli.

Alan Carneiro e Filomena de Souza - Abril de 2009

(Pesquisa para Monografia de Conclusão de Curso)

No meu encontro com estas professoras pude perceber que de fato, apropriar-se do discurso acadêmico não é uma tarefa simples, principalmente no caso delas que se propunham, em suas pesquisas, em suas aulas, apropriar-se também da cultura e da história de Timor, assumindo uma função de retransmissão. Esta apropriação num certo sentido só poderia ser problemática, pois dizer pelo viés de uma mulher, implica em questionar o poder de quem determina a cultura, a história, a identidade e a lingua, significa subverter estruturas de poder muito arraigadas. Em alguns momentos implica em subverter modos tradicionais de dizer e de se apropriar da fala, para fortalecer e fazer com que sejam ouvidas as vozes que são silenciadas.

\section{Mais um viajante em Timor}

O principal e mais importante da minha trajetória em Timor, foi o contato com estas alunas que se tornaram minhas amigas, hoje me instiga saber o que pensam os jovens e as crianças, mais da metade da população do país. Os jovens de Timor-Leste, os alunos das minhas alunas professoras, bem como seus filhos, ouvem rock e rap, assistem 
seriados indonésios e americanos, querem aprender inglês, os que estão no ensino médio, ou na faculdade, quase não falam português e ainda sonham com a Indonésia, a Austrália ou com Portugal como porto de passagem para um mundo globalizado. Mas há também os jovens que andam nas ruas vendendo produtos dependurados em bambus para os malaes, há os jovens nas montanhas, nas suas comunidades que reproduzem muito dos modos de vida ancestrais.

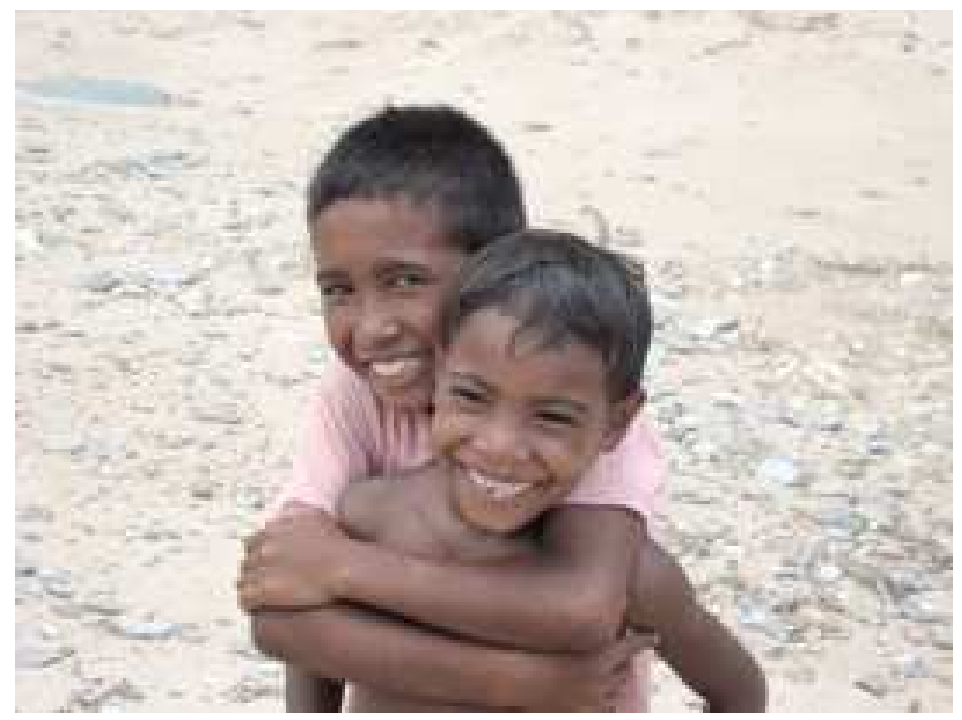

Crianças na praia colhendo mariscos, Baucau.

Alan Carneiro - Setembro de 2008

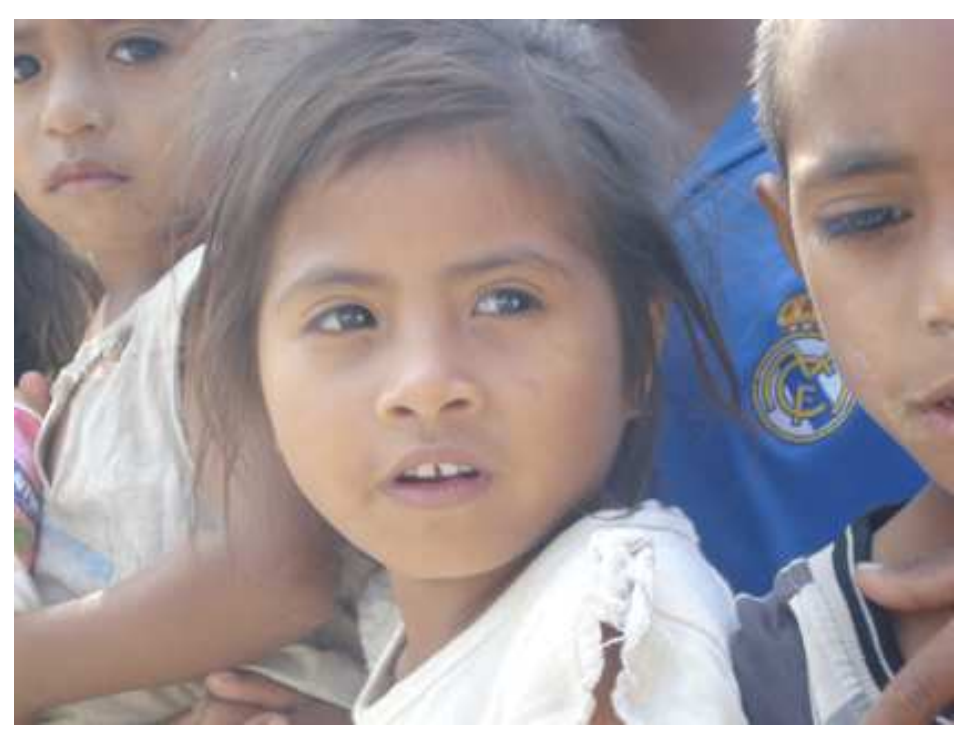

Crianças na praia vendendo artesanato para turistas, Com. Alan Carneiro - Setembro de 2008 


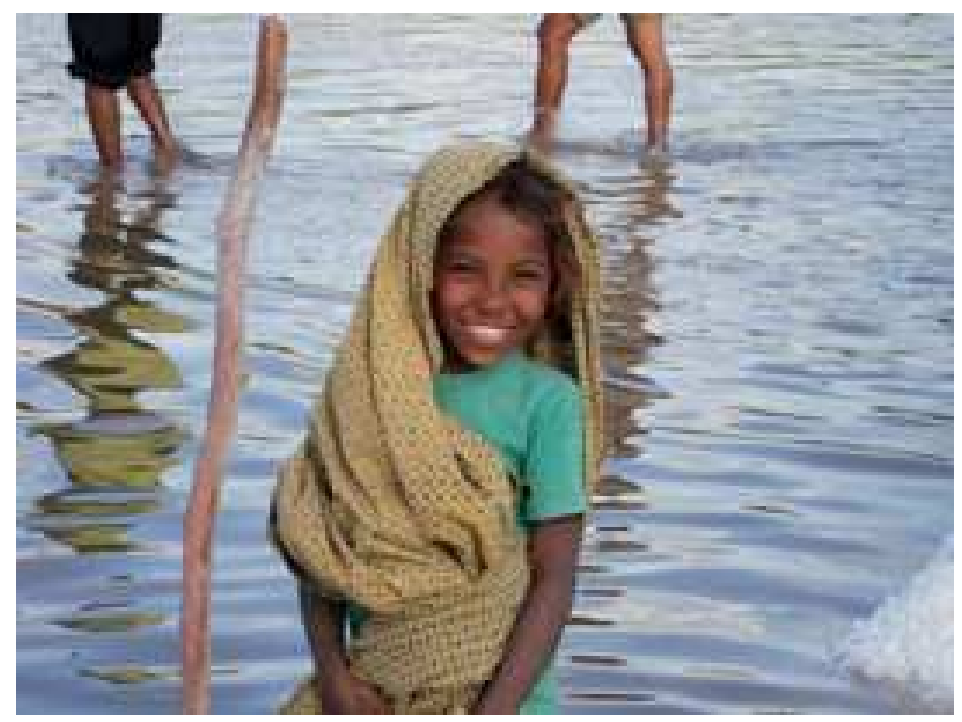

Criança trabalhadora de uma salineira, Laga.

Alan Carneiro - Setembro de 2008

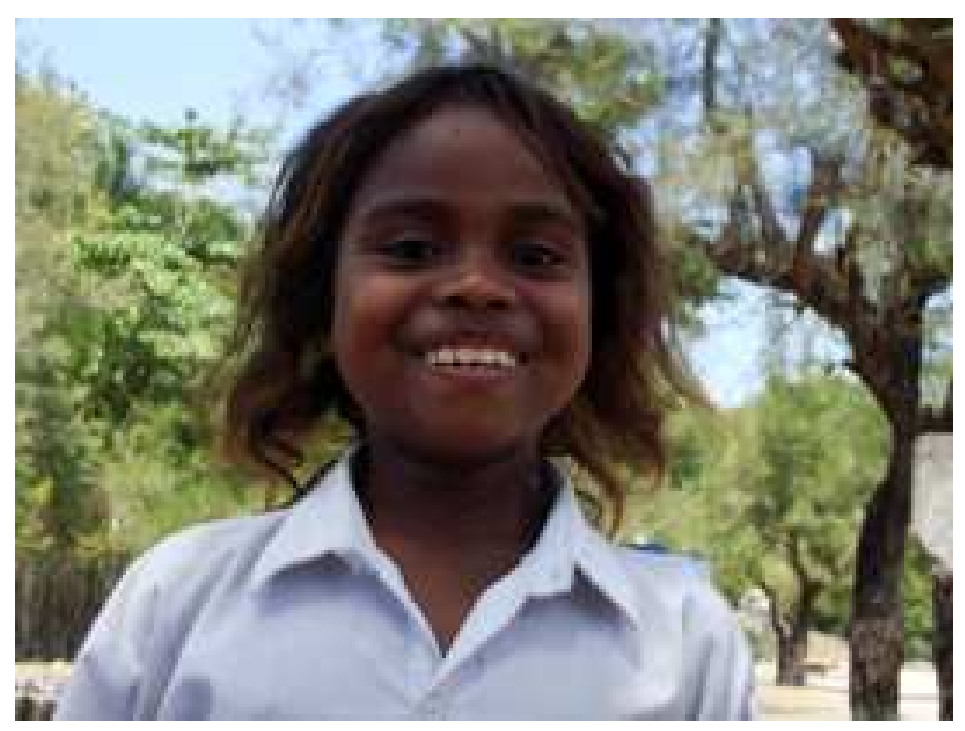

Estudante na saída da escola, Viqueque.

Alan Carneiro - Novembro de 2008

Ao longo deste breve relato espero ter dimensionado pouco de Timor e um tanto da minha experiência como professor brasileiro de lingua portuguesa neste território. Certamente não tenho a estatura de Cinatti para tratar os timorenses como irmãos, uma vez que dentre os viajantes que foram à Timor, o poeta foi o que mais se entregou à tarefa de conhecê-los e de dedicar sua vida a eles. Mas certamente espero poder tratar a todos os timorenses que conheço e os que porventura eu 
vier a conhecer como amigos, quero não esquecê-los com a distância que nos separa, desejo que fique em mim sempre, saudades de Timor.

\section{Referências bibliográficas}

CINATTI, R. Paisagens Timorenses com Vultos. Lisboa: Relógio D’Agua Editores, 1996.

FOREMAN, M. Down in Dili. Disponivel em: http://www.martinforeman.com/world/dili.html Acesso em $20 / 10 / 2010$.

NEVES, G. N. S. “O paradoxo da cooperação em Timor-Leste”. In: SILVA, K. SIMIÃO, D. S. (Orgs.) Timor-Leste por trás do palco: Cooperação internacional e a dialética da formação do Estado. Belo Horizonte: Editora UFMG, 2007.

PIGAFETTA, A. "Primeira Viagem à volta do mundo". In: LOUREIRO, R. (Coord.). Onde nasce o sândalo: os portugueses em Timor nos séculos XVI e XVII. Lisboa: Grupo de Trabalho do Ministério da Educação para as Comemorações dos Descobrimentos Portugueses, 1995.

PRATT, M. L. Os olhos do império: relatos de viagem e transculturação. Bauru: EDUSC, 1999.

SAID, E. Orientalismo: o oriente como invenção do ocidente. São Paulo: Companhia das Letras, 2003.

TIMOR-LESTE: O Massacre que o Mundo Não Viu. Direção: Lucélia Santos. 2001. Duração: 75 min. 
SILVA, K. SIMIÃO, D. S. (Orgs.) Timor-Leste por trás do palco: Cooperação internacional e a dialética da formação do Estado. Belo Horizonte: Editora UFMG, 2007. 